\title{
PATIENT-CITIZEN-CONSUMERS: JUDICIALIZATION OF HEALTH AND METAMORPHOSIS OF BIOPOLITICS*
}

\author{
João Biehl
}

is Susan Dod Brown Professor of Anthropology and Facul-ty Associate of the Woodrow Wilson School of Public and International Affairs at Princeton University. He is also the co-director of

Princeton's Global Health Program, Princeton, USA. Email <jbiehl@princeton.edu >

http://dx.doi.org/10.1590/ 0102-6445077-105/98

\section{Critical global health}

The people targeted by global health and development plans are not flat and homogenous, and are not just the source of problems or so-called cultural obstacles. People and the worlds they navigate and the outlooks they articulate are more confounding, incomplete, and multiplying than dominant analytical schemes tend to account for. Epistemological breakthroughs do not belong to experts and analysts alone; people's practical knowledges can help break open and transform paradigms, and may well provide the keys to an otherwise. Building from this commitment to people-centered knowledge production, in the book

\footnotetext{
* This article draws from a research project developed with Adriana Petryna, Mariana Peixoto Socal and Joseph Amon, and I am deeply grateful for their incredible collaborative efforts and sharp critical insights throughout the years. I am also thankful to Naomi Zucker for her wonderful editorial help. I presented an early version of this essay at a meeting of the working group on Critical Global Health Studies at Johns Hopkins University. Thank you to Jeremy Greene, Clara Han, and all participants for the lively discussion and helpful comments. Thank you, also, to Deisy Ventura for her editorial support. Whenever requested, the names of actors and institutions have been changed to protect their anonymity.
} 
When people come first, anthropologist Adriana Petryna and I make the case for an ethnographic empirical lantern in the critical studies of global health (Biehl and Petryna, 2013b). That is, we advocate for charting the lives of individuals and institutions over time, chronicling people's varied interpretations of their conditions, all the while denaturalizing operational categories and illuminating the concrete ways meso- and macro-level actors impinge on local worlds and become part of global orders (Biehl and Petryna, 2014).

Close attention to particular realities and to the various technologies and metrics in which they are cast highlights the productive and fraught coexistence between global health systems design and the alternative models people craft for "engaging the real... [and for] 'worlding' the world," as Clifford Geertz (2007, p. 222) put it. They attune us to the places where global inequities and ideologies - neocolonialism, neoliberalism, governmentality, humanitarian 78 reason - are reified, and to those categories' limits. Ethnography can thus capture the active embroilment of reason, life, and ethics, offering entry points into the plasticity of systems, theorizers, and norm-makers themselves and leaving space for pursuing new forms of socially meaningful anthropological work in global health. Instead of withdrawing to a dispassionate "armchair" position and easily cynical dismissal, this kind of work inhabits the tension between a critique of and in global health, sustaining a space for critical inquiry and action, understanding and doing.

Over the years, these questions and concerns have informed my own ethnographic work, which has traced how science and technology move from the laboratory to health policy and popular discourse, and from professional medicine to domestic economies and the intimate realms of bodily experience, particularly in contexts of stark inequality. My major projects have explored the new geographies and politics of access and marginalization that have 
emerged in Brazil alongside pharmaceutical globalization, particularly around mental illness and human immunodeficiency virus/Acquired Immune Deficiency Syndrome HIV/Aids (Biehl, 2005, 2007a, 2007b).

A major player in the politics of pharmaceuticals in the global South, and boasting a universal health care system guaranteed by law, Brazil has offered fertile ground for thinking through the often-unanticipated ways that people seek out treatment from the State and the market. So, with my "empirical lantern," I have focused on the forms of mobilization and circuits of care through which poor patients and families struggle to make livable lives in wounded cities, attending to the social, technological, legal and political entanglements that enable transformation at various levels, alongside those that debilitate people or foreclose their life chances.

My current ethnographic project builds from these core concerns and addresses the meeting points of Medicine and Law in contemporary Brazil. I am particularly interested in how people work through available legal mechanisms and the Judiciary to claim access to medical technologies and care, and in how the Judiciary - in representing this emergent technological society - is becoming a critical site of politics. This article draws from collaborative multisited ethnographic research and legal analysis on what has been termed the judicialization of the right to health in Brazil and across Latin America.

\section{The judicialization of health}

"Judicialization increases health inequity." So reads a recent headline in Folha de S.Paulo, one of Brazil's most influential newspapers (Colucci, 2014). The report presents research on the growing phenomenon of lawsuits over access to medicines in the State of São Paulo, emphasizing that two thirds of these lawsuits are filed by people with private 
health insurance or who attend private clinics, and concluding that they "originate from rich areas and concentrate on high-cost treatments."

While the justiciability of socioeconomic rights is of increasing interest internationally, the volume of individual right to health lawsuits in Brazil stands out (Biehl et al., 2012; Dittrich et al., 2016; Gauri and Brinks, 2008; Pepe et al., 2010; Reveiz et al., 2013; Yamin and Gloppen, 2011). Tens of thousands of cases are brought to courts annually, particularly for access to pharmaceuticals. With the increasing number of cases has come controversy over the phenomenon and its consequences (Azevedo, 2007; Ferraz, 2009, 2011; Messeder, Osorio-de-Castro and Luiza, 2005; The Economist, 2011).

The article in Folha de S.Paulo presents judicialization as a scandal of the "haves" triumphing over the "have-nots," a view promoted by government officials and public health scholars. For example, Brazil's former Health Minister 80 has said that lawsuits seeking medicines "take resources away from the poorest to benefit those who have more." "It's a kind of Robin Hood in reverse," added São Paulo's Health Secretary: "to take from the poor to give to those who can afford to pay for a good lawyer." The director of Brazil's Cochrane Center for evidence-based medicine has speculated that the pharmaceutical industry is responsible for judicialization: "Why does no one file a lawsuit for the government to give calcium to pregnant women and prevent hypertension? Because calcium does not cost anything, there is no lobby behind it" (Colucci, 2014).

According to such narratives, judicialization is driven by urban elites seeking high-cost drugs that are not part of governmental formularies. People who judicialize are portrayed as well-off litigants exploiting the expansiveness of the country's constitutional right-to-health, undermining public health policies and furthering private-sector interests that constrain and deplete good government. 
In this article, I present empirical evidence that refute narratives depicting judicialization as a harbinger of inequity and an antagonist of the public health system. I show that right-to-health litigation is in fact a widespread practice, accessible even to the very poor. Judicialization has, to a large extent, become an alternate path for people to access health care when administrative mechanisms fail them, and it may actually serve as an instrument to hold the State accountable for workable infrastructures.

\section{Reimagining political subjects}

Over recent years, I have been working with research collaborators in the U.S. and Brazil to develop a quantitative and qualitative portrait of the people who are turning to judicialization and to illuminate their travails, particularly in the southern State of Rio Grande do Sul (Biehl, Socal and Amon, 2016; Biehl, 2013, 2016; Biehl and Petryna, 2013c). With a population of 11 million people, the State has seen a sharp increase in health-related lawsuits in the past decade, rising from 1,126 new cases in 2002 to 17,025 new cases in 2009. Roughly $70 \%$ of these lawsuits were for access to medicines (Biehl et al., 2012). By 2011, it had the highest number of health-related lawsuits in the country, with more than 100 thousand pending cases (Bassette, 2011).

What is extraordinary in right-to-health litigation is not simply its ever-growing numbers, but the fact that it allows for the reentry of human voices into public debates about the object and scope of the right to health, the nature of care through and beyond technology, and the public-private interface in contemporary governmental institutions. The experiences of lawyers, patients and families, doctors, advocates, policy makers, and judges do not, and cannot, perfectly cohere; the judicialization of health is not seamless, but it represents a heterogeneous phenomenon that compels sick people, laws, experts, officials, and medical 
technologies to shuttle between home, hospital, public offices, and courtroom, remaking those spaces and themselves. This "peopling of technologies" (Fischer, 2013), combined with the plasticity of jurisprudence, is thus fertile ground for exploring new forms of subjectivation and political action.

"If I hadn't studied Philosophy, I would have studied Law," the philosopher Gilles Deleuze stated in a series of interviews he gave in the late 1980s (Deleuze, 2011). Not the universal rights of man, Deleuze continued, but jurisprudence. "That's what life is; there are no 'rights of man,' only rights of life, and so, life unfolds case by case." While talk of universal rights is, for Deleuze, only empty intellectual abstraction - "it's zero philosophically, zero" -, jurisprudence reveals people directly concerned with surviving and desiring in "concrete", "abominable", and "crazy" situations: "To act for freedom, becoming revolutionary, is to operate 82 in jurisprudence when one turns to the justice system [...]. That's what the invention of law is."

Jurisprudence is a domain of practical rights and involves a particular sort of immanence. The Latin root means a "knowledge" of law, and this knowledge can only be generated through the iterative process of bringing the law to bear on real-world contexts. Jurisprudence does not depend on an a priori subject; rather, the production of subjects is one effect of jurisprudence.

Nowhere were these shifting institutional and subjective forms more evident than in the class action suit that was filed on August 10th, 2001, on behalf of the Federal Public Ministry of Porto Alegre (Brazil), to secure access to gender-affirming care for transgender people. "I was the pioneer", Luan, a transgender man, told me in a conversation at his home. Luan's transition in the 1980s, still considered experimental by Brazilian health authorities at the time, required seven surgeries, all of which he had to pay 
for himself. "It made a $100 \%$ difference, I became a new person." All the identity documents from his previous life as a woman are now a "state secret," Luan said - no one can access them. "That person has been erased."

A retired teacher and a happily married man, Luan believes in the transformative power of politics. He has long been active in the Workers' Party, but after a narrow loss in a campaign for city representative, he decided to focus his activism on poor women's reproductive health. There were no established health services for transgender people during Luan's transition in the 1980s, but his work paved the way for the founding of the "Program for Gender Identity Disorder" in 1997, the first program of its kind in Brazil. Although the clinic itself was founded through the efforts of a coalition of health professionals, Luan's convictions became the seed of a new political collective: he was the founding president of the state's transgender patients' association. As an activist of an earlier generation, he did not benefit from an established political collective, he told me, and so he has become a mentor to younger transgender people as they face discrimination and precariousness of all kinds and traverse their own transformations.

Attorney Paulo Leivas, who led the team that filed the lawsuit, says that people do not trust the country's administrative systems. He views his Public Ministry, by contrast, as a mechanism of critique that can make bureaucracies more "porous." Leivas added that transgender people, unlike the gay activist groups that coalesced in the 1990s in response to Aids, did not organize to the same extent or find a collective political voice. He implied that his office played a key role in translating individual struggles, like Luan's, into political ones. The lawsuit he filed argued that transition-related care was a medical necessity within a biomedical logic of gender identity disorder, and that access to the treatment was guaranteed under Brazil's constitutional right to health. 
On August 14th, 2007, Judge Roger Raupp Rios wrote the decision on this class action suit on behalf of a federal appellate court, which ordered the country's universal health care system to provide free access to transition-related care (Brasil, 2001). In his decision, however, Rios argued against the pathologization of gender variance, stating that "in reality, the biomedical perspective underlies the so-called 'gender binary." Instead of focusing on the right to health, his ruling affirmed the more general rights of "liberty, equality, non-discrimination, and respect for human dignity" for transgender people. However, the Supreme Court tried to suspend this ruling, alleging that it improperly constituted policy-making, and stipulating, instead, that each case should be judged individually.

Both Leivas's lawsuit, which relied on a pathological understanding of transgender identity, and the edict of the Supreme Court, which rejected Judge Rios's claim to collec84 tive rights on a non-medicalized basis, hint at practical limits of judicialization, equating citizenship to individualized state-mediated access to the therapeutic market. Yet the discourse of Judge Rios's decision points to another possibility: a budding form of agency that speaks to the limits of normalization and control, as well as to the transgressive force of alternative collectives and of singularizing oneself out the population. In the wake of all this legal mobilization, in 2008, the Ministry of Health finally added transition-related care to the list of services provided by the public health system (Brasil, 2008).

Amidst shifting legal discourses and ongoing claims to rights, what kind of political subjects does judicialization thus render legible? Neither entirely controlled by nor fully accountable to the State or to the market, those who inhabit this new subject position use jurisprudence to negotiate their own naturalness, and to navigate the constraints and possibilities of a technological society. Working through the 
available legal mechanisms, they instantiate new socio-medico-legal domains to engage and adjudicate their demands, making abstract human rights concrete.

As Deleuze (2011) argued, universal human rights are fallacious; the capacity to act upon the law is what gives it efficacy. I am suggesting that the appearance of new political subjects in democratizing Brazil rests upon people's knowledge of the legal system and their capacity to act through it. This individual ability to act within the system is facilitated by translators or intermediary agents like Leivas and Rios. Such expert public representatives are able to assure access to legal technologies and the rights they afford, all the while translating critical theory into practice. As Rios invokes the "gender binary" in court, he takes up the language of gender theorists, turning the South into a kind of laboratory of alternative law. The mediation of multiple forms of knowledge within and across spheres here brings into the court new frames for imagining and demanding rights. These developments, in turn, end up consolidating the Judiciary as a critical site of politics - and political economy.

\section{Patient-citizen-consumers}

A retired bus driver, Edgar Lemos, lives in a lower-middle-class neighborhood of the state capital, Porto Alegre. Dealing with significant motor difficulties, Edgar had to wait for more than a year for an appointment with a neurologist at a nearby public hospital. He was finally diagnosed with hereditary cerebral ataxia in November 2008, and was prescribed the drug Somazina, which is not included in any governmental drug formulary. Raised in a destitute family, Edgar had been working since the age of eight. He was proud of the gated brick and mortar house he had built himself on the top of a hill. Edgar's ataxia affected not only his mobility but also his sense of dignity and worth, as it made him dependent on the care of his wife and two adult daughters. 
While Edgar felt that Somazina was helping to halt the degeneration of his motor abilities, he was also taking other drugs, from statins to antihypertensives to antidepressants, to soothe additional symptoms.

At his dining room table, Edgar opened a box containing the five medicines that make up his regimen. As he held each one in turn, he said, "This one I don't judicialize, this one I don't judicialize [...] This one I don't judicialize [...] I only judicialize this medicine because I got into debt paying for it." A monthly supply of Somazina costs about 200 dollars. After paying for the drug out of pocket for several months, Edgar had to take out a bank loan. Unable to keep up with household expenses and the interest on his loan, he said that he had "no alternative but to judicialize," and filed a lawsuit with the help of the Public Defender's Office.

Edgar's case speaks to both an emergent form of 86 political subjectivity and its points of contact with the public sphere. His case was handled by attorney Paula Pinto de Souza, who says that the Public Defender's Office has become "a juridical hospital." As an advocate for the poor and chronically ill, she considers it her job to ameliorate suffering and to restore her client's rights. "The person," she explains, "comes here sick and wronged by the failure of public policies. We are beyond preventive medicine here and the concept of health as physical, mental and social well-being is no more."

A district judge issued a court injunction on Edgar's behalf, and he received the medicine for several months, until "the delivery stopped." He then filed a new claim, winning another injunction for three additional months of treatment. As for why he was not judicializing the other drugs he was taking, Edgar reasoned, "I know that the State cannot give everything to everyone. I have to do my part and pay for whatever I can.” 
The lawsuit is only one part of Edgar's labyrinthine treatment ordeal, and even the efficacy of his own medication was uncertain. Judicialization is not an attractive option to begin with. Although it saves him money, Edgar must periodically renew the lawsuit, with no guarantee that drug delivery will continue. In some sense, Edgar prefers the position of consumer to that of citizen, as it gives him more control and confidence. The market, in this case, is more reliable than the welfare state. The medicine box is Edgar's survival kit. Yet what does not fit in this box is the psychosocial care, for example, that could help Edgar improve his quality of life as the disease progresses. A lawsuit would not help him gain access to such services.

Stories like Edgar's illuminate the complex and overlapping subject positions that individuals occupy as they procure precarious access to treatment through the market and the courtroom, balancing clinical needs with shifting boundaries of personal and public responsibility. While examining tense negotiations of the constitutional right to health in daily life, I often had a sense that social roles and institutional positions were out of place: the Judiciary was acting as a sort of pharmacy, the public defender as a physician, the physician as an activist, the patient association as legal counsel; the patient-citizen was becoming a consumer, and cost-cutting public officers had kidnapped the discourse on equity.

\section{The metamorphosis of biopolitics}

Michel Foucault's tentative reflections on biopolitics and neoliberalism (Foucault, 2008) are helpful in grappling with these novel medico-socio-legal realities and translocations. In neoliberal societies, Foucault (2008, p. 30) posits, the market is left to function with the least possible intervention so that it can "both formulate its truth and propose it to governmental practice as rule and norm." Henceforth, 
he argues, "good government is no longer simply government that functions according to justice" (p. 32); rather, it is the free market that "binds and manifests political bonds" (p. 85). Civil society is thus reduced to a transactional realm of free, self-interested subjects.

The realities I chronicled in Brazil in some ways confirm this move toward increasingly marketized versions of politics and citizenship. Yet they also contravened Foucault's reflections, marking a surprising return of the juridical subject in late-liberal political economies. Here, the shift that Foucault suggests from people to population, and from homo juridicus to homo economicus, does not hold as neatly as he wants it to. In the judicialization of health, the penetration of market principles in the delivery of care is unexpectedly aligned with the juridical subject of rights. The rational choice-making economic subject (necessarily a consumer of technoscience) is at the same time the subject of legal rights. The right to living 88 is thus claimed somewhere in between the clinic, the court, and the marketplace. What do these processes of judicialization mean for how anthropologists approach the study of politics and engage with ongoing debates, inside and outside the academy, about the relationship of health to human rights and social justice? How are the interpenetrating domains of health, therapeutic markets, and the law emerging as implicit and explicit sites for claiming political rights and confronting infrastructural failures?

There is no predetermined strategy of control in what I came to think of as a judicial para-infrastructure. With this term, I mean to call attention to, and account for, the interstitial domain of political experimentation that becomes visible in people's case-by-case attempts to "enter justice" in Brazil. Norms are constantly in flux, and numerous parties - State and market institutions as well as experts, legal representatives, and patient-citizens - may manipulate various levers of access. Widespread right-to-health litigation 
thus reveals the possibility for individually-driven inclusions which puncture the public space of populations - not by introducing new norms, but by leveraging existing ones through case-based jurisprudence. In this emergent form of mobilization, people instrumentalize or eschew collective roles, elude institutions manipulated by market-driven state functionaries, and claim rights through their own needs. Although precarious, such para-infrastructures significantly inform people's ways of living in the context of ailing or inadequate public institutions, revealing the scope and reach of governance in real time. How, then, do we understand this new kind of juridico-political order emanating from the global south?

\section{Pharmaceuticalization}

Let me place these questions - if only cursorily - in historical perspective. Two concurrent and paradoxical trends informed the structure of Brazil's universal health care system (known as SUS - Sistema Único de Saúde) which extended health coverage to all citizens in the late 1980s. On one hand, there was a trend towards a greater recognition of the role of government in the fulfillment of social rights in the democratic Brazilian Constitution of 1988. On the other hand, a neoliberal theory of government emphasized decentralization and outsourcing of State functions to the private sector. While the Federal Government assumed a central role in public healthcare funding, regional and municipal health secretariats had to develop new structures to assess health needs and to manage funds for the delivery of care. This arrangement produced a delegation of responsibility without ensuring funding compliance or technical capacity for implementation.

Thus, although Brazil today has highly progressive health policy, many people go to public pharmacies only to find that essential medicines are out of stock and that 
the newer medicines they seek - as in Edgar's case - are not included in official drug formularies. Today, the various tiers of government (municipal, state, federal) are responsible for purchasing and distributing medicines according to specific formularies (Brasil, 2010; Porto, Uga, and Moreira, 2011). In practice, governments at all levels have not been able to effectively manage a complex health care system under increasing technological, infrastructural and economic demands from the public and private sectors, which themselves are becoming increasingly indistinguishable.

Public opinion has rallied against the overworked and under-resourced health care system. As Brazil's current crisis shows, state resources are being used and depleted to shore up particular political projects and interests (Nobre, 2013; Romero, 2015), while the public continues to insist on the need of infrastructural developments and the importance of social services; as a recent survey showed, an over90 whelming amount of $45 \%$ of Brazilians list health as the country's principal concern (Leite, 2014).

As I documented in the book Will to live: Aids therapies and the politics of survival (Biehl, 2007a), Aids activists were among the first to successfully equate the constitutional right to health with access to pharmaceuticals (Luo et al., 2014). And this form of activism has fast migrated not just to other patient advocacy groups, but to the general population (Messeder, Osorio-de-Castro, and Luiza, 2005). Prior to the availability of antiretroviral drugs (ARVs), the fight against HIV in Brazil emphasized knowledge, empowerment, and the recognition of how stigma and social marginalization led to infection. However, these are hard issues to address, and as ARVs became more readily available, the response emphasis shifted to a more biomedical, less comprehensive approach. What we are seeing now in Brazil is how this biomedical shift has affected the way various health issues are conceptualized and addressed. 
In terms of both delivery and demand, public health is now understood less as prevention and primary care and more as access to medicines and community-outsourced care; that is, public health has become increasingly pharmaceuticalized and privatized (Biehl, 2007b; Biehl and Petryna, 2014). In this process, the country is becoming a profitable platform for global medicine, with one of the fastest-growing pharmaceutical markets in the world (Sindusfarma, 2012). It is estimated that almost $50 \%$ of adults in Brazil (about 60 million people) use pharmaceuticals on a daily basis. The judicialization of the right to health does not resist or belie these trends, and critics have repeatedly asserted that it is an elite phenomenon, which generates enormous administrative and fiscal burdens, distorts pharmaceutical policies, widens inequalities in health care access, and encourages irrational drug use.

\section{Judicialization from below and the quest for State accountability}

There is an emerging body of scholarship on right-to-health litigation, but most studies tend to corroborate the views of public health administrators (Campos Neto et al., 2012; Chieffi and Barata, 2009, 2010; Ferraz, 2009; Gomes and Amador, 2015; Da Silva and Terrazas, 2008; Vieira and Zucchi, 2007; Wang and Ferraz, 2013). Yet the evidence for these claims is too-often obscured by ideological arguments and constrained by small samples, limited geographic coverage, and examination of very few variables. Throughout these works - which are ostensibly concerned with fairness and equity -, individual demands are presented as the antithesis of a supposed collective need, and actual people - their health-seeking struggles, hopes, and outcomes - are nowhere to be found.

Wedded to evidence-based public health, many of these critics fail to recognize that right-to-health litigation can be an urgently needed corrective when administrative channels 
fail people, and that judicialization can itself be a source of practice-based evidence, offering clues on how to improve health systems. People-centered approaches can link us to a register of social change that need not pass by way of the distantly removed mechanisms of State or political economy.

To respond to the need for more realistic knowledge of the struggle to realize the right to health, our team created two databases of lawsuits requesting medicines from the State of Rio Grande do Sul. The first was a convenience sample of 1,080 cases (see Biehl et al., 2012). To create our second database, we accessed the Health Secretariat's electronic registry and, after selecting a random starting point, we systematically collected every sixth case opened during 2008 - totaling 1,262 cases in the sample (Biehl, Socal, and Amon, 2016). The results of our analysis of this database - which represents the largest number of lawsuits seeking access to medicine in Brazil to date - challenge many com92 mon assumptions about right-to-health litigation in Brazil, offering an empirical counter to widely circulated views.

Of this litigant population, $54 \%$ were female and $92 \%$ lived outside the state capital, showing how geographically widespread the phenomenon is. Individuals who judicialize are also predominantly older. While past research has suggested that right-to-health litigation in Brazil is, for the most part, a practice of the financially better off, our findings show this to be false, at least in Southern Brazil. Among the plaintiffs who reported their employment status, more than half were either retired or unemployed. Although we did not have direct data on income, $58 \%$ of plaintiffs were represented by the Public Defender's Office, which provides free legal assistance only to individuals proven to live below the poverty line.

Our data also found misconceptions about the character and cost of medications sought. Overall, $73 \%$ of all plaintiffs requested at least one medicine that was part of 
governmental drug formularies (on-formulary). Forty-one percent of the plaintiffs requested on-formulary medicines exclusively, while $27 \%$ (like Edgar) requested off-formulary medicines exclusively. The vast majority of cases $(80 \%)$ indicated that treatment was requested for a continuous duration, reflecting the chronic character of the diseases that afflict these patient-citizens. The most frequently requested medicines were for common problems, such as asthma, hypertension, cholesterol, and mental illness. They were part of official drug formularies and had therapeutic protocols defined by the Ministry of Health. Most patients had comorbidities and required multiple medicines (an average of 2.7 per lawsuit).

These results suggest that government pharmaceutical programs are failing to fulfill their role of expanding access and rationalizing use, and that the poor are trying to make the system redress this failure. Contrary to common claims, litigants mostly sought low-cost drugs. Like Edgar, the vast majority $(75 \%)$, requested medicines with a monthly cost below 250 dollars. High-cost lawsuits composed the minority of the sample. Overall, on- or off-formulary medicines did not diverge significantly in terms of cost.

Just as the majority of plaintiffs requested medicines that were part of governmental drug formularies, a large number of plaintiffs also initially tried to secure treatment through local administrative channels. Eighty-five per cent of lawsuits included a physician-issued prescription or a report confirming the need for treatment. Strikingly, in almost all of the lawsuits, the judges granted the plaintiffs an immediate injunction demanding the State to provide the requested drugs, explaining this was consistent with Brazil's constitutional obligations to fulfill the right to health.

To investigate whether judges took governmental norms for drug provision into consideration, we also analyzed the frequency with which judges ruled on the provision 
of generics. In the 837 rulings in which there was explicit reference to the drug form, judges mandated the provision of generics in $76 \%$ of cases. Concerned with whether judicialization leads to policy reforms, we checked whether the 329 off-formulary medicines that had been requested by the plaintiffs in 2008 were subsequently introduced in the public health system. By 2014, $18 \%$ of these medicines had been incorporated into the governmental formularies. Among the 20 most frequently requested off-formulary medicines in our sample, seven have been incorporated into governmental formularies since 2008, including the most expensive one.

Counter to prevailing narratives, our results thus reveal a process of "judicialization from below," stemming from low-income and older individuals who do not live in major metropolitan areas, and who depend on the State to provide their legal representation. In addressing a dysfunc94 tional health system that fails to provide for their needs, poor patients face the option of exiting the public system (seeking private sector alternatives), or voicing concerns through cumbersome and slow political and participatory mechanisms like voting or community councils. Our study shows that through right-to-health litigation, some Brazilian citizens are finding new ways of concretizing voice (Hirschman, 1970) through a process of "entering justice," acting as political subjects to hold the State accountable and exposing the Realpolitik of executive and legislative bodies.

Like attorney Paula Pinto de Souza, Judge Eugênio Terra (who oversees all health-related lawsuits in Porto Alegre), finds that lawsuits are largely filed by poor and desperate patients seeking treatments that should be available in the public system. "I am doing social justice, one by one," he told me in an interview. "When I am issuing an injunction for cancer treatment provision, I am also indicting services that have not kept up with people's needs." 
Our study also showed that when patients sought new technologies not yet included in (obsolete) benefits packages, the State tended to incorporate the requested technologies into official policies posteriorly. While in no way a magic bullet for broader structural political problems, judicialization can thus be understood as a crucial mechanism of both accountability and responsiveness, highlighting gaps in the system and sometimes - however modestly - addressing them.

It is possible that the presence of strong, accessible and widespread public institutions such as the Public Defender's Office act as important enablers of judicialization. Rio Grande do Sul has a much higher volume of right-to-health litigation than other Brazilian states. These differences reflect the varied performance of the decentralized health care system throughout the country, as well as the significant differences in economy, demography, and administrative capacity within and across the 26 Brazilian states. Our research suggests that there is likely a relationship between stronger public institutions and more intense judicialization and, thus, while judicialization may reduce inequalities within a State, it might have little impact on inequalities across states. At the very least, the heterogeneity of rightto-health litigation across Brazil suggests a need for more nuanced and in-depth analysis of its drivers and implications at local levels.

\section{Social becoming}

Sixteen-year-old Leticia and nine-year-old Katiele are the daughters of Marizete and Neri, part of a migrant family living on the outskirts of Porto Alegre. Both suffer from phenylketonuria or PKU, a metabolic genetic disorder. The difference is that the younger sister, Katiele, was immediately diagnosed and treated with a combination of diet and medication; Leticia, the older, was not, and she now 
suffers from severe intellectual disability. Leticia was only diagnosed because her sister was born after screening had become mandatory, and the special baby formula needed to prevent the development of the disease had become universally available via the public health care system.

In the State of Rio Grande do Sul, about 120 patients need this formula. But given distribution problems, 25 families had to file lawsuits to ensure access. We interviewed all these litigant families who, for the most part, live in the interior and are in fact poor. Like Marizete and Neri, they all have low levels of formal education. But this does not stop them from judicializing.

Marizete and Neri told us that they were receiving the baby formula through the health system, but they had decided to file lawsuits to obtain the special food (like pasta and flour) that is vastly more expensive than the common foods that the sisters are unable to eat, and which took up 96 much of the family's budget. Once, when the State failed to make the formula available, the couple considered filing a lawsuit for it, as well. At the very last moment, however, the family decided not to because Doctor Paula Vargas, the girls' beloved physician, and other families, lent them their own formula until distribution resumed. As Marizete puts it, "When one mother gets something, she teaches the others. So one keeps helping the other, until we get it."

Leticia and Katiele's family found something that they identified as preferable to going through the courts: a caring and aware health professional and a social network. Doctor Vargas helped to create and sustain solidarity among her patients, facilitating the sharing of the formula and mutual support among families living with PKU. "When the formula is lacking, families can call me any time and I'm sure I can do something even when the State is not doing its job," Doctor Vargas told me. "These patients simply cannot go without the treatment. It would be a crime." 
As the cases of Edgar, Leticia, and Katiele show, the booming number of right-to-health lawsuits simultaneously reveals the weakness of administration and policy in Brazil, and highlights the ways in which the Judiciary has indeed become a powerful purveyor of access to medical technology. They also bring into focus the problems with a widespread reductionist approach to care: in spite of its universality, health care delivery is stuck in an access and volume mindset, rather than focusing on the value delivered to patients (Kim, Farmer, and Porter, 2013). Yet, new social forms are emerging at the interface of right-to-health litigation, medical technology, and the State. Where institutions fail, communities articulate fragile and short-range solutions - and these solutions can teach us that social ties are often the last and best resource in the face of disregard and the will to survive and care.

\section{Counter-conducts}

Policy makers contend that the Judiciary is overstepping its role, and that judicialization skews budgets and increases inequalities in health care access. However, many local judges working on right-to-health cases feel they are responding to State failures to provide the needed medicines, and that these waves of lawsuits are a milestone in the democratization of a culture of rights. For these judges, the poor Brazilians who are working through modes of legally-arbitrated justice to access health care are not just fighting against legalized privileges and legitimated inequalities. Rather, they see widespread litigation as the expression of a distinct, equalizing legal system and of a novel rights-conscious society.

But for Miriam Ventura, who was one of the first lawyers to pursue litigation on behalf of Aids patients, "judicialization today is a question of individual consumption." The judicial activism of the 1990s used individual lawsuits to lay broad claim to collective rights and the demand of health 
policy solutions, she told us in an interview. While Aids judicial activism created "a strong subject of rights [...] so that those people could be recognized as citizens," contemporary judicialization no longer represents that kind of social mobilization, she lamented. Even for patient's associations, "the Judiciary is not treated as a political instrument, it is merely instrumental."

In her critique, Ventura assumes a certain kind of political subject, one that recognizes and represents him or herself as such, and she regrets the dying out of the civil society paradigm for politics. But is there another possibility for citizenship in Brazil today that can navigate between a State that presents itself as activist and socially protective (beyond the minimum neoliberal State) and emerging therapeutic markets via local solidarities?

In the final lecture of Security, territory, population, Foucault (2007) intimated that future forms of civil "counter-conduct" might emerge in response to crises of governmentality. He leaves unanswered the forms that such counter-conducts may take, unsure of what modalities of struggle or resistance could possibly be efficacious in a neoliberal landscape. He recognized only that any such attempt would have to find new openings in the machinations of the State. Perhaps the stories of these patient-citizens, with their fusion of sociability and instrumentality, may provide a window onto one such possibility.

Medical commodities can also work in tandem with other ways of claiming rights and normalcy, and desperate and creative interactions occasion novel public sites alongside the emergence of novel political subjectivities. Twelve-year-old Alexandre suffers from mucopolysaccharidosis (MPS), an inherited metabolic disorder. If access to Aids therapies was the litmus test of the right to health in the 1990s, today it is the access to genetic therapies (Biehl and Petryna, 2013c; Diniz, Medeiros, and Schwartz, 2012). Every week, the fourth 
grader travels with his mother, Cleonice, to Hospital de Clínicas in Porto Alegre, where he receives enzyme replacement therapy, a treatment that costs about 200 thousand dollars per year. Because of his age, Alexandre was not allowed to enroll in a clinical trial taking place at the hospital. Without "the right to be researched," as the mother of another MPS patient put it, Alexandre became a patient-litigant.

With the legal support of a well-organized patient association in São Paulo (partially funded by the drug manufacturer), the family won a court injunction forcing the Federal Government to begin providing the therapy. Like all parents of MPS children we spoke to, Cleonice suggested that not obtaining this treatment would be unconscionable and tantamount to killing her child. She knew that the federal attorneys would appeal and was ready for the struggle: "Besides entering the Judiciary, we also entered the media." Cleonice has taken Alexandre's cause to all possible media outlets, and is also using his condition to educate neighbors, local medical personnel, and officials about the meaning of, in her words, "citizenship" and a "normal life." "She is a good mother," says Alexandre, who is thriving in school and seems to be responding positively to treatment.

$* * *$

Health is a major concern for the new Brazilian population, and right-to-health litigation is a widespread practice, accessible even to low-income patients. Judicialization has become both a last resort and an alternate path to access to health care in the context of a progressive universal health system that coexists with a problematic decentralization, and in which an accelerated pharmaceuticalization and privatization of care has taken the place of infrastructural reform.

The patient-citizen-consumers I introduced throughout the article, and thousands of others, find their way into the 
Judiciary reluctantly, tinkering with available human and material resources, and the judicialization of health has become a para-infrastructure through which the chronically ill and various public and private actors come into contact, face off, and enact "one by one" rescue missions. By striving to escape exclusions and remedy the failures of the State, litigants may not be establishing an immanent civil society, but they are establishing themselves as people. They are working to reintroduce human voices into public debates about the right to health and its tenuous limits. This minimum biopolitical belonging is part and parcel of the immanent fields people invent to live in as they navigate the vagaries of market inclusion and survival. As ethnographers, we must attend to these forms of statecraft, and to the kinds of evidence and political subjectivities built into the parainfrastructure of rights and interests that the judicialization of health has occasioned.

100 Countries have legitimate concerns about regulating new and high-cost medicines, and resource constraints mean that trade-offs will inevitably occur (Dittrich et al., 2016; Yamin, 2014). They face difficult decisions about allocating funding for pharmaceuticals or towards targeting the social determinants of health, especially within contexts of aging populations, increasing life expectancies, and the rise of non-communicable diseases. Brazil's experience highlights the importance of ensuring explicit and functional mechanisms for participation, transparency and accountability in health systems. It also illustrates the significant role of counter-publics and the Judiciary in monitoring the quality of health care and assessing the need for new medical technologies amidst competing and contested considerations of value, cost-effectiveness and efficiency.

People refuse to be stratified out of existence, using any means available to poke holes in the macro models and population-level calculations that would hold their lives 
captive or delimit their chances. These hard-to-pin-down patient-citizen-consumers speak to novel forms of social becoming at the interface of Law and Medicine. Their medico-legal trajectories show that politics matters differently to a growing number of sick low- and middle-income Brazilians. Their stories also illuminate the temporal dimensions of medical technologies, and the power of these technologies to remake subjectivities and social worlds, as they open up new spaces for claim making, contestation, and ethical problematization.

It is only through critical ethnographic work that such stories, trajectories, and mechanisms come into view. Going against the grain of appearances and affirming dissensus, this study thus illuminates the improvised quality of late liberal democratic institutions of government and challenges the remodeled logics of today's inequality. It also breaks open a distinct sense of public mobilization and politics inthe-making, where people, amid dire infrastructural conditions, find means of holding the State locally accountable.

\section{João Biehl}

is Susan Dod Brown Professor of Anthropology and Faculty Associate of the Woodrow Wilson School of Public and International Affairs at Princeton University. He is also the co-director of Princeton's Global Health Program.

\section{References}

AZEVEDO, S. 2007. Remédios nos tribunais. Revista Época, Dec.

12. Available at: <http:/ / revistaepoca.globo.com/Revista/

Epoca/0,,ERT59499-15257,00.html>. Accessed on: March 6, 2016.

BASSETTE, F. 2011. RS reúne metade das ações judiciais de saúde. $O$

Estado de S. Paulo, Apr. 29. Available at: <http://www.estadao.com.

$\mathrm{br} /$ noticias/geral,rs-reune-metade-das-acoes-judiciais-de-saudeimp-,712418>. Accessed on: March 6, 2016.

BIEHL, J. 2005. Vita: life in a zone of social abandonment. Berkeley: University of California Press. 
2007a. Will to live: Aids therapies and the politics of survival. Berkeley: University of California Press.

2007b. Pharmaceuticalization: Aids treatment and global health politics. Anthropological Quarterly, v. 80, n. 4, pp. 1083-126.

. 2013. The judicialization of biopolitics. American Ethnologist, v. 40, n. 3, pp. 419-36.

2016. The postneoliberal fabulation of power: on statecraft, precarious infrastructures, and public mobilization in Brazil. American Ethnologist, v. 43, n. 3, pp. 437-50.

BIEHL, J.; PETRYNA, A. (eds.). 2013a. When people come first: critical studies in global health. Princeton: Princeton University Press.

. 2013b. Critical global health. In: BIEHL, J.; PETRYNA, A. (eds.). When people come first: critical studies in global health. Princeton: Princeton University Press.

.2013c. Legal remedies: therapeutic markets and the judicialization of the right to health. In: BIEHL, J.; PETRYNA, A. (eds.). When people come first: critical studies in global health. Princeton: Princeton University Press.

2014. Peopling global health. Saúde e Sociedade, v. 23, n. 2, pp. 376-89.

102 BIEHL, J.; SOCAL, M. P.; AMON, J. J. 2016. The judicialization of health and the quest for State accountability: evidence from 1,262 lawsuits for access to medicines in Southern Brazil. Health and Human Rights, v. 18, n. 1, pp. 209-20.

BIEHL et. al. 2012. Between the court and the clinic: lawsuits for medicines and the right to health in Brazil. Health and Human Rights, v. 14, n. 1, pp. 1-17.

BRASIL. Ministério da Saúde. 2008. Portaria ${ }^{\circ}$ 1.707, de 18 de agosto. Available at: <http:/ /bvsms.saude.gov.br/bvs/saudelegis/gm/2008/ prt1707_18_08_2008.html>. Accessed on: March 6, 2016.

. 2010. Protocolos clínicos e diretrizes terapêuticas. Brasília: Ministério da Saúde.

BRASIL. Ministério Público. 2001. Apelação cível nº 2001.71.026279-9/RS. Brasília: Ministério Público Federal e União.

CAMPOS NETO, O. H. et al. 2012. Doctors, lawyers and pharmaceutical industry on health lawsuits in Minas Gerais, Southeastern Brazil. Revista de Saúde Pública, v. 46, n. 5, pp. 784-90.

CHIEFFI, A. L.; BARATA, R. C. B. 2009. "Judicialization” of public health policy for distribution of medicines. Cadernos de Saúde Pública, v. 25, n. 8 , pp. 1839-49. 
2010. Legal suits: pharmaceutical industry strategies to introduce new drugs in the Brazilian public healthcare system. Revista de Saúde Pública, v. 44, n. 3, pp. 421-28.

COLUCCI, C. 2014. Judicialização faz desigualdade na saúde avançar. Folha de S.Paulo, Mar. 29. Available at: <http:/ /www1.folha.uol.com.br/ fsp/especial/158639-judicializacao-faz-desigualdade-na-saude-avancar. shtml>. Accessed on: March 6, 2016.

DA SILVA, V. A.; TERRAZAS, F. V. 2008. Claiming the right to health in Brazilian Courts: the exclusion of the already excluded. The Social Sciences Research Network (SSRN). Available at: <http:/ / papers.ssrn.com/ sol3/papers.cfm?abstract_id=1133620>. Accessed on: March 6, 2016.

DELEUZE, G. 2011. Gilles Deleuze from A to Z. USA: Semiotext(e).

DINIZ, D.; MEDEIROS, M.; SCHWARTZ, I. V. 2012. Consequences of the judicialization of health policies: the cost of medicines for mucopolysaccharidosis. Cadernos de Saúde Pública, v. 28, n. 3, pp. 479-89.

DITTRICH, R. et al. 2016. The international right to health: what does it mean in legal practice and how can it affect priority setting for universal health coverage? Health Systems E Reform, v. 2, n. 1, pp. 23-31.

FERRAZ, O. L. M. 2009. The right to health in the courts of Brazil: worsening health inequities? Health and Human Rights Journal, v. 11, n. 2, pp. 33-45.

2011. Harming the poor through social rights litigation: lessons from Brazil. South Texas Law Review, v. 89, n. 7, pp. 1643-68.

FISCHER, M. M. J. 2013. The peopling of technologies. In: BIEHL, J.; PETRYNA, A. (eds.). When people come first: critical studies in global health. Princeton: Princeton University Press.

FOUCAULT, M. 2008. The birth of biopolitics: lectures at the College de France 1978-1979. New York: Palgrave Macmillan.

2007. Security, territory, population: lectures at the College de France 1977-1978. New York: Palgrave Macmillan.

GAURI, V.; BRINKS, D. M. 2008. Courting social justice: judicial enforcement of social and economic rights in the developing world. Cambridge, UK: Cambridge University Press.

GEERTZ, C. 2007. To exist is to have confidence in one's way of being: rituals as model systems. In: CREAGER, A.; LUNBECK, E.; WISE, M. N. (eds.). Science without laws: model systems, cases, exemplary narratives. Durham: Duke University Press.

GOMES, V. S.; AMADOR, T. A. 2015. Studies published in indexed journals on lawsuits for medicines in Brazil: a systematic review. Cadernos de Saúde Pública, v. 31, n. 3, pp. 451-62. 
HIRSCHMAN, A. O. 1970. Exit, voice, loyalty: responses to decline in firms, organizations and states. Cambridge, MA: Harvard University Press.

KIM, J. Y.; FARMER, P.; PORTER, M. 2013. Redefining global health care delivery. The Lancet, v. 382, n. 9897, pp. 1060-69.

LEITE, M. 2014. Datafolha aponta saúde como principal problema dos brasileiros. Folha de S.Paulo, Mar. 29. Available at: <http://www1.folha. uol.com.br/seminariosfolha/2014/03/1432478-datafolha-apontasaude-como-principal-problema-dos-brasileiros.shtml $>$. Accessed on: March 6, 2016.

LUO, J. et al. 2014. Antiretroviral drug expenditure, pricing and judicial demand: an analysis of federal procurement data in Brazil from 20042011. BMC Public Health, v. 14, pp. 367.

MESSEDER, A. M.; OSORIO-DE-CASTRO, C. G. S.; LUIZA, V. L. 2005. Mandados judiciais como ferramenta para garantia do acesso a medicamentos no setor público: a experiência do Estado do Rio de Janeiro, Brasil. Cadernos de Saúde Pública, v. 21, n. 2, pp. 525-34.

NOBRE, M. 2013. Imobilismo em movimento: da abertura democrática ao governo Dilma. São Paulo: Companhia das Letras.

PEPE, V. L. E. et al. 2010. Characterization of lawsuits for the supply of "essential" medicines in the State of Rio de Janeiro, Brazil. Cadernos de 104 Saúde Pública, v. 26, pp. 461-71.

PORTO, S. M.; UGA, M. A. D.; MOREIRA, R. S. 2011. Uma análise da utilização de serviços de saúde por sistema de financiamento: Brasil 1998-2008. Ciência Ẽ Saúde Coletiva, v. 16, n. 9, pp. 3795-806.

RANCIÈRE, J. 2001. Ten theses on politics. Theory and Event, v. 5, n. 3, pp. $1-16$.

REVEIZ, L. et al. 2013. Litigios por derecho a la salud en tres países de América Latina: revisión sistemática de la literatura. Revista Panamericana de Salud Pública, v. 33, n. 3, pp. 213-22.

ROMERO, S. 2015. Scandals in Brazil prompt fears of a return to turmoil. The New York Times, Aug. 12.

SINDUSFARMA - Sindicato da Indústria de Produtos Farmacêuticos no Estado de São Paulo. 2012. Indicadores econômicos: vendas em dólares (US\$). Available at: <http:/ /www.sindusfarmacomunica.org.br/ indicadores-economicos $>$. Accessed on: March 6, 2016.

THE ECONOMIST. 2011. An injection of reality. Jul. 30. Available at: <http:/ /www.economist.com/node/21524879>. Accessed on: March 6, 2016.

VIEIRA, F. S.; ZUCCHI, P. 2007. Distortions to national drug policy caused by lawsuits in Brazil. Revista de Saúde Pública, v. 41, n. 2, pp. 214-22. 
WANG, D. W. L.; FERRAZ, O. L. M. 2013. Reaching out to the needy?

Access to justice and public attorneys' role in right to health litigation in the city of São Paulo. SUR International Journal on Human Rights, v. 10, n. 18, pp. 159-79.

YAMIN, A. E. 2014. Promoting equity in health: what role for courts? Health Human Rights, v. 16, n. 2, pp. 1-9.

YAMIN, A. E.; GLOPPEN, S. 2011. Litigating health rights: can courts bring more justice to health? Cambridge, MA: Harvard University Press. 


\section{PATIENT-CITIZEN-CONSUMERS: JUDICIALIZATION OF HEALTH AND METAMORPHOSIS OF BIOPOLITICS}

\section{JOÃO BIEHL}

Abstract: Situated at the meeting points of Law and Medicine, the "judicialization of the right to health" is a contested and hotly debated phenomenon in Brazil. While government officials and some scholars argue that it is driven by urban elites and private interests, and used primarily to access high-cost drugs, empirical evidence refute narratives depicting judicialization as a harbinger of inequity and an antagonist of the public health system. This article's quantitative and ethnographic analysis suggests, instead, that low-income people are working through the available legal mechanisms to claim access to medical technologies and care, turning the Judiciary into a critical site of biopolitics from below. These patient-citizenconsumers are no longer waiting for medical technologies to trickle down, and judicialization has become a key instrument to hold the State accountable for workable infrastructures.

Keywords: Judicialization of Health; Pharmaceuticalization; Critical Global Health; Biopolitics from Below; Patient-Citizen-Consumers; State Accountability; Workable Infrastructures.

\section{PACIENTES-CIDADÃOS-CONSUMIIDORES: A JUDICIALIZAÇÃO DA SAÚDE E A MIETAMORFOSE DA BIOPOLÍTICA}

Resumo: Situada na convergência entre direito e medicina, a "judicialização do direito à saúde" é um fenômeno contencioso que tem gerado debates acalorados no Brasil. Enquanto agentes públicos e alguns acadêmicos sustentam que ela é dirigida por elites urbanas e interesses privados e é acionada, primordialmente, para acessar medicamentos de alto custo, evidências empíricas refutam narrativas que descrevem a judicialização como um indicador de desigualdade e um antagonista do sistema público de saúde. A aná- 
lise quantitativa e etnográfica deste artigo sugere, em vez disso, que pessoas de baixa renda trabalham, por meio de mecanismos legais disponíveis, para reivindicar o acesso a cuidados e tecnologias médicas, tornando o Judiciário um espaço crítico para articulação de uma biopolítica de base. Esses pacientes-cidadãos-consumidores não mais esperam que as tecnologias médicas se redistribuam gradativamente, e a judicialização se tornou um instrumento essencial para a responsabilização do Estado por infraestruturas eficazes.

Palavras-chave: Judicialização da Saúde; Farmaceuticalização; Saúde Global Crítica; Biopolítica de Base; Pacientes-Cidadãos-Consumidores; Responsabilidade Estatal; Infraestruturas Eficazes.

Recebido em: 18/3/2016 Aprovado em: 17/6/2016 